MAGDALENA BOGUSŁAWSKA

Uniwersytet Warszawski

e-mail: m.boguslawska@uw.edu.pl

\title{
Kulturowe aspekty recepcji serbskiego dramatu w polskim teatrze współczesnym
}

\author{
Abstract \\ The Cultural Aspects of Serbian Drama's Reception in Polish Contemporary Theatre
}

The text concerns the reception of contemporary Serbian drama in Poland, namely cultural aspects of its theatrical adaptation. Dušan Kovačević and Biljana Srbljanović text stagings, usually issued Serbian authors on the Polish scenes, reveal the persistence of certain strategies for the "Other" perception. They are based primarily on the orientalism and balkanization matrices, although the creators of the performances more often than on the imaging of serbness focusing on diagnosing a Polish historical, social and cultural experience by reference to texts that were formed in the conditions of crisis. A separate part of the article was devoted to the ventures of etnological-artistic Polish alternative theatres, that in their work are inspired by Balkan (also Serbian) phenomenon of ritual drama.

Keywords: Serbian drama, Serbia, Polish theatre, intercultural relations, otherness, cultural translation.

Słowa kluczowe: serbski dramat, Serbia, polski teatr, relacje międzykulturowe, inność, przekład kulturowy

\section{Teatr jako spotkanie}

Temat niniejszego artykułu: dramat serbski w polskim teatrze współczesnym, kojarzony niejako automatycznie $\mathrm{z}$ zagadnieniem recepcji dzieła dramatycznego czy też dramatyczno-teatralnego, zgodnie z tradycją sugeruje, że należałoby dotyczące tej kwestii rozważania sytuować w nurcie ujęć deskryptywno-kronikarskich. Przy takim założeniu omówienie tematu trzeba by potraktować jako działanie w pierwszym rzędzie dokumentacyjne, w myśl oczywistej prawdy, że opis przedstawienia teatralnego pozostaje - wobec ulotności samego zdarzenia scenicznego - trwałym świadectwem i źródłem wiedzy o danym spektaklu. Innymi słowy, tego rodzaju podejście sugeruje trwanie w kręgu idiograficznie sprofi- 
lowanych badań historyczno-teatralnych. Tymczasem zawarta w tytule tradycjonalistyczna formulacja nie musi oznaczać metodologicznego zobowiązania, a co za tym idzie nie nakłada na badacza metodologicznych ograniczeń. Wręcz przeciwnie - mamy wszelkie prawo uznać, że w istocie rzeczy w centrum zainteresowania znajduje się tu całe spektrum zagadnień wykraczających poza filologicznie zorientowaną refleksję dramatologiczną, spośród których za fundamentalny można uznać problem relacji międzykulturowej, wyrażającej się poprzez działania artystyczne - w interesującym nas przypadku poprzez konkretne przedsięwzięcia sceniczno-adaptacyjne. Można tym samym przyjąć, że temat niniejszego artykułu, widziany przez pryzmat wartości komunikacyjno-kulturowych, stanowi badawcze wyzwanie, a zarazem wiąże się z określoną propozycją metodologiczną, by w tym wypadku dramat i teatr rozpatrywać $\mathrm{z}$ perspektywy komparatystycznie ukierunkowanej hermeneutyki kulturowej, przesuwając akcent z zapisu historyczno-teatralnego na kontekst społeczny i światopoglądowy, a zwłaszcza na kwestie imagologiczne.

W interesującym nas przypadku przestrzenią połączenia obu stanowisk metodologicznych: teatrograficznego (czyli faktograficznego opisu utworów teatralnych) i kulturologicznie zorientowanej refleksji hermeneutycznej, staje się refleksja ksenologiczna, która pozwala potraktować teatr, scenę, inscenizację, a także działania reżysera i aktora jako przestrzeń spotkania z inną, obcą kulturą - nawet wówczas, gdy owa odmienność kulturowa nie jest wprost problematyzowana $\mathrm{w}$ utworze dramatycznym i/lub spektaklu będącym jego realizacją. Nawet jeśli motywacją dla scenicznej realizacji danego dramatu jest całkowita z nim identyfikacja, pozostaje on przecież reprezentacją zakorzenionego w określonej kulturze obrazu świata, z kolei spektakl teatralny dzięki takiemu podejściu może być rozpatrywany nie tylko pod względem wartości estetycznych, ale także przez pryzmat porządku idei, wyobrażeń, emocji, których jest tworem i wyrazicielem.

Owo spotkanie z - definiowaną tu jako etniczna, narodowa, kulturowa - innością serbskiego dramatopisarstwa i - szerzej - kultury teatralnej dokonywać się może na co najmniej dwa sposoby. Po pierwsze, w przypadku teatru repertuarowego, tak profesjonalnego, jak amatorskiego, nośnikiem jej wyobrażeniowych reprezentacji staje się $\mathrm{z}$ reguły przekład i sceniczna interpretacja tekstu dramatu. Obraz ten jest zatem zazwyczaj zapośredniczony przez wizję zaproponowaną przez autora sztuki i to autorytet autora staje się dla twórców przedstawienia swoistym filtrem w spojrzeniu na daną wspólnotę i rzeczywistość kulturową, którą owa społeczność stwarza i w której funkcjonuje. Oczywiście zazwyczaj jest ona interesująca dla twórcy teatralnego o tyle, o ile można za jej pośrednictwem (a więc z pewnym pozwalającym na krytycyzm dystansem oraz za pomocą transformacji znaczeniowej) mówić odbiorcom dzieła o nich samych, o świecie, którego są uczestnikami, a nierzadko także gospodarzami. Tego rodzaju analogie czy też identyczności, zwłaszcza te głębokie, istotowe, których wykazanie prowadzi do zawieszenia prostej dychotomii swojskość - obcość, mają zatem ważkie znaczenie, jeśli traktować je jako punkt wyjścia dla rozumienia inności, próg otwarcia na nią. 
Po drugie, w przypadku scen niezależnych, poszukujących, tych, które ze spotkania z Innym czynią modus operandi, mamy do czynienia z odwołaniami do tradycji autochtonicznych - funkcjonujących np. w postaci kultury widowiskowej typu ludowego, w formie praktyk i tekstów folkloru - jako materii działania teatralnego. W tym wariancie owo spotkanie przybiera postać złożonych, metodycznie realizowanych przedsięwzięć z pogranicza nauki, np. etnologii/antropologii i sztuki, a ta jako taka pomyślana jest jako rodzaj wymiany, którą w języku antropologii teatru Eugenio Barba sygnuje mianem barteru ${ }^{1}$. To, co zostaje zaczerpnięte z doświadczenia Innego (jako przedstawiciela odmiennej kultury), staje się tu nie tylko budulcem spektaklu, lecz także istotnym elementem metody twórczej, pożywką warsztatu artystycznego, a także inspiracją dla oryginalnej filozofii teatru.

$\mathrm{Na}$ gruncie polskim zainteresowanie serbską twórczością dramatyczną i teatralną, a także lokalnym światem widowisk manifestuje się w obu wskazanych tu wariantach. I niezależnie od tego, czy twórcy osią problemową swych przedsięwzięć scenicznych czynią kwestie społeczne, polityczne, psychologiczne, czy też estetyczne, metateatralne, związane z kształtowaniem nowego, osobnego języka teatru, za każdym razem kontekstem tych działań pozostaje - podejmowany wprost lub pośrednio - wysiłek konceptualizacji własnego kulturowego samookreślenia w wymiarze zarówno kolektywnym, jak i jednostkowym, a także problem umiejscowienia w tym projekcie tożsamościowym doświadczenia inności. Jest to inność z perspektywy polskiej nieoczywista, poboczna, peryferyjna, której percepcja ma charakter raczej okazjonalny. Fakt ten z jednej strony oznaczać może pożądany w działaniu artystycznym, bo stymulujący, ruch myśli i pracę wyobraźni, brak rutyny, z drugiej zaś może prowadzić do ujęć stereotypizujących, skazujących na poznawczy automatyzm i bierność. Znaczącą rolę odgrywają w tym procesie recepcji tłumacze, którzy zazwyczaj decydują o wyborze tekstów i dokonują ich ,polonizacji”, polegającej nie tylko na językowej, czysto filologicznej ekwiwalencji², lecz także na dbałości o to, by serbskie lub - szerzej - bałkańskie idiomatyzmy kulturowe stały się czytelne dla polskiego odbiorcy bez szkody dla wartości oryginalnego dramatu jako swoistego dokumentu czy też reprezentacji lokalnej rzeczywistości społecznej, historycznej, politycznej. Tu dotykamy złożonego zagadnienia etyki przekładu, które, czego dowodzi Maria Dąbrowska-Partyka, staje się wyjątkowo newralgiczne w przypadku literatur uznawanych za małe, egzotyczne i niezbyt oryginalne, łatwo skazywanych na marginalizację i/lub powielanie klisz zubażających przekaz ${ }^{3}$.

1 Praktykowana przez Eugenia Barbę i jego Odin Teatret zasada barteru polega na międzykulturowej wymianie doświadczeń i form artystycznych pomiędzy grupą aktorów a odmienną kulturowo społecznością tradycyjną, do której zespół dociera, wzorem antropologów. Teatralny barter ma w zamyśle twórców stanowić rodzaj obrzędowej wymiany darów, będącej fundamentem tworzenia więzi.

2 M. Dąbrowska-Partyka, Poleżeć na liściach laurowych, albo czego nie wolno tlumaczowi [w:] Świadectwa i mistyfikacje. Przed i po Jugosławii, Kraków 2003, s. 309.

3 Ibid. 


\section{(Post)polityczność jako klucz recepcji}

Obecność dramaturgii serbskiej w Polsce do połowy XX wieku ma właściwie charakter incydentalny, a jej kontekst stanowi ogólna percepcja Serbii (ale też Bałkanów i Jugosławii) w jej specyfice historycznej, etnicznej, kulturowej i religijnej. Wydaje się, iż w owym pierwszym okresie motywem zainteresowania tym krajem jest, wskazany przez romantyków, a zakorzeniony w dziewiętnastowiecznej idei słowianofilstwa, argument etnicznego (słowiańskiego) pokrewieństwa Serbów i Polaków - dostrzeganego przede wszystkim w sferze języka oraz folkloru - a także przekonanie o podobieństwie losów historycznych oraz istnieniu analogii w sposobach formowania tożsamości i prawa do samostanowienia obu narodów w warunkach walki o wyzwolenie spod obcej dominacji. Trwałość paradygmatu romantycznego w obu kulturach przez długi czas wydaje się wystarczającym oparciem dla łączących je relacji i zasadniczą podstawą wzajemnej percepcji i rozumienia.

Dramaturgia serbska XIX i pierwszej połowy XX wieku bywa postrzegana w Polsce zasadniczo jako receptywna wobec twórczości europejskiej, a jednocześnie zbyt ściśle związana z lokalnymi (by nie powiedzieć prowincjonalnymi) realiami, aby mogła głębiej zainteresować polskich twórców teatralnych, zorientowanych w tym okresie bądź na afirmację repertuaru narodowego, bądź na recepcję repertuaru światowego, zwłaszcza twórczości dramatopisarzy rosyjskich i zachodnioeuropejskich, która w Polsce zawsze stanowiła zasadniczą sferę odniesienia $^{4}$. Sytuacja ulega poprawie po drugiej wojnie światowej, przy czym dokonania serbskich autorów, zgodnie z ówczesnym stanem rzeczy, są traktowane jako przynależne do jugosłowiańskiej przestrzeni literackiej i teatralnej, a przekładom dramatów i ich inscenizacjom sprzyja polityka kulturalna PRL-u, nastawiona na prezentację polskiej publiczności dzieł z państw socjalistycznych (z uprzywilejowaną pozycją ZSRR). Niemniej na scenach pojawiają się przedstawienia inscenizowane na podstawie dramatów takich autorów, jak: Branislav Nušić (Gospođa ministarka / Pani ministrowa; Sumnjvo lice / Podejrzany osobnik), Đorđe Lebović (Haleluja / Alleluja; Himmelkommando), Jovan Hristić (Savonarola i njegovi prijatelji / Sawonarola i jego przyjaciele), Velimir Lukić (Dugi život kralja Osvalda / Dtugie życie króla Oswalda; Zavera ili dugo praskozorije / Spisek czyli dtugie świtanie; Santa Maria della Salute), a miesięcznik „Dialog” publikuje przekłady tekstów wybranych dramatopisarzy z Jugosławii, w tym także z Serbii (obok już wymienionych są to: Aleksandar Popović, Borislav Pekić i inni) ${ }^{5}$.

W przeciągu ostatnich dwu-trzech dekad, naznaczonych przełomowymi wydarzeniami politycznymi, społecznymi i cywilizacyjnymi, o znaczeniu zarówno

4 Przed drugą wojną światową premiery doczekała się zaledwie jedna serbska sztuka, a mianowicie Gospođa ministarka (Pani ministrowa), wystawiona w Krakowie w 1938 r., w przekładzie z języka niemieckiego (sic!); zob. H. Kalita, Bibliografia jugoslovenske drame na pozornicama u Poljskoj 1910-1985, „Scena” 1986, br. 6.

5 Warto w tym miejscu przypomnieć również Antologię współczesnego dramatujugosłowiańskiego, opracowaną przez Ognjena Lakićevicia (Łódź 1988), w której znalazły się także dramaty autorów serbskich Jovana Hristicia, Dušana Kovačevicia, Velimira Lukicia i Aleksandra Popovicia. 
lokalnym, jak i ponadlokalnym, na scenach polskich najczęściej inscenizowane są utwory dwojga dramatopisarzy: Dušana Kovačevicia i Biljany Srbljanović, reprezentantów odpowiednio starszego i młodszego (Kovačević urodził się w 1948, Srbljanović w 1970 roku) pokolenia twórców. Z tego też względu w dalszych rozważaniach skoncentruję się na teatralnej recepcji wybranych tekstów właśnie tych autorów. Najliczniej przekłady dramatów obojga publikował miesięcznik „Dialog”, stanowiący od lat główne, a także gwarantujące wysoki poziom i reprezentatywność, forum prezentacji najnowszej dramaturgii światowej. Ponadto tekst Srbljanović Barbelo, o psach i dzieciach w przekładzie Doroty Jovanki Ćirlić ukazał się w antologii Postpolityczność. Antologia nowego dramatu serbskie$g o^{6}$.

Początki zainteresowania twórczością Kovačevicia w Polsce przypadają na przełom lat 80. i 90., lecz pozostaje on autorem obecnym w polskiej percepcji także w pierwszej dekadzie XX wieku. Wydaje się, że na uznanie dla sztuk tego autora w istotnym stopniu oddziałuje jego współpraca z filmem, a zwłaszcza z Emirem Kusturicą, do którego filmów, znanych również w Polsce, Ojciec w podróży stużbowej (Otac na službenom putu) oraz Underground, Kovačević napisał scenariusze. W każdym razie fakt tej współpracy jest przypominany przez polskich komentatorów jego twórczości jako swoista rekomendacja, która ma dowodzić renomy oraz rozpoznawalności stylu serbskiego autora, a także jego otwarcia na nowoczesne media i przekaz popularny.

Z dorobku Kovačevicia polska publiczność mogła oglądać inscenizacje trzech dramatów: Bałkański szpieg (Balkanski špijun) ${ }^{7}$, Larry Thompson - dramat pewnej młodości (Lari Tompson - tragedija jedne mladosti) ${ }^{8}$ i Profesjonalista (Profesjonalac) $)^{9}$ W tym wyborze kluczowa wydaje się zbieżność problemowa utworów. Zwłaszcza dramaty Bałkański szpieg i Profesjonalista tworzą swoisty dyptyk, ukazujący w różnych odsłonach czasowych logikę totalitaryzmu, mechanizmy zniewolenia: etycznego, intelektualnego, mentalnego. Na początku obecnego wieku polski teatr zainteresował się przede wszystkim Profesjonalista, na co z pewnością wpływ miał sukces, jaki odniosła na świecie filmowa ekranizacja utworu w reżyserii samego autora. Jednak dla polskich odczytań owego faustyczno-groteskowego egzemplum pociągająca była przede wszystkim aktualność te-

6 Postpolityczność. Antologia nowego dramatu serbskiego, wybór i red. G. Injac, Kraków 2011, s. $191-255$.

7 Batkański szpieg został wystawiony na deskach Teatru Nowego w Łodzi (reż. Grzegorz Sobociński, premiera 11.01.1986 r.), Bałtyckiego Teatru Dramatycznego w Koszalinie (reż. Józef Fryźlewicz, premiera 10.01.1987 r.), Lubuskiego Teatru w Zielonej Górze (reż. Marek Chełminiak, premiera 5.03.1987 r.) oraz Teatru Dramatycznego w Elblągu (reż. Sylwester Szyszko, premiera 10.04.1987 r.). Dane na podstawie: D. Szałęga, Obecny Nieobecny. Polska recepcja dramatów Dušana Kovačevicia, „Slavica Wratislaviensia” CLIV, 2011, s. 52.

8 Polska premiera spektaklu Larry Thompson-dramat pewnej młodości w reżyserii Krzysztofa Kopki odbyła się 6.11.1999 r. w Teatrze im. H. Modrzejewskiej w Legnicy. Ibid.

9 Profesjonalista został wystawiony przez Krzysztofa Zaleskiego w gdańskim Teatrze Wybrzeże (premiera 12.11.2004 r.), a także przez Ryszarda Bugajskiego w Teatrze Telewizji (25.03.2005 r.) oraz Bogdana Cioska w Teatrze Zagłębia w Sosnowcu (premiera 10.09.2005). Ponadto w 2005 r. na podstawie dramatu Kovačevicia Jerzy Fedorowicz wyreżyserował słuchowisko radiowe. Ibid. 
matu, jak i odkrywana na nowo zbieżność doświadczeń obu postsocjalistycznych krajów. Otóż właściwym kontekstem inscenizacji z tego okresu stały się wzmożone przez sytuację polityczną spory na temat potrzeby i metod dekomunizacji, a także zasad funkcjonowania instytucji zaangażowanych w ten proces. Aktualizowany politycznie temat dzięki inscenizacjom dramatu Kovačevicia zyskał swe artystyczne reprezentacje, spośród których najsilniejszy rezonans miał spektakl przygotowany przez Ryszarda Bugajskiego dla Teatru Telewizji, a wyemitowany w programie pierwszym TVP 28 lutego 2005 roku.

Dla Bugajskiego, autora filmu Przestuchanie (1982) oraz spektaklu telewizyjnego Miś Kolabo (2001) - utworów poświęconych działalności służb bezpieczeństwa, ważna okazała się zaproponowana przez serbskiego dramatopisarza diagnoza opresyjnego funkcjonowania systemu totalitarnego na poziomie indywidualnych relacji międzyludzkich, psychiki i mentalności społecznej, ujawniająca etyczną dwuznaczność przenikającą stosunki zależności, relacje władzy ${ }^{10}$. Jednocześnie podobieństwo historycznego doświadczenia stanowiło gwarancję czytelności przesłania polskich wystawień Profesjonalisty, z kolei element różnicujący, czyli specyficzna w swej konstrukcji kulturowej serbskość, utożsamiona z dość sztampowo wyobrażoną bałkańskością (w inscenizacji jest to zakrapiana rakiją biesiada i rozbrzmiewające w tle pieśni), uwzględniona została zaledwie na prawach ornamentu - o czym dowodnie świadczyć może spektakl telewizyjny Bugajskiego. Zresztą redukcja tego, co specyficznie lokalne do elementu ,rozpoznawalnego kolorytu" wydaje się standardową praktyką, stosowaną w adaptacji tych obcych sztuk, po które się sięga z uwagi na ich publicystyczny potencjał, pozwalający na włączenie danej wypowiedzi artystycznej w aktualną debatę publiczną ${ }^{11}$.

Rozważania na temat polskiej recepcji Profesjonalisty należy sytuować w znacznie szerszym kontekście zagadnień związanych ze stosunkiem do komunistycznego dziedzictwa w krajach postsocjalistycznych/posttotalitarnych. Zwłaszcza że zarówno potoczna percepcja, jak i krytyczny namysł elit nad tym historycznym doświadczeniem w przypadku Serbów i Polaków przebiega nieco inaczej. I nie chodzi tu wyłącznie o odmienności związane z różną sytuacją ekonomiczną w obu krajach w okresie socjalizmu: (względny) dobrobyt w Jugosławii - jeden z podstawowych argumentów jugonostalgii i fetysz jugonostalgików - i nieporównywalnie niższe standardy życia w PRL-u, które w dzisiejszych ocenach, formułowanych w warunkach dominacji kultury konsumpcyjnej, skłaniają do mówienia o minionym okresie jako czasie „cywilizacji niedoboru”. Otóż istotne różnice stają się zauważalne wówczas, gdy rozważamy ucieleśnione przez SFRJ i PRL doświadczenie komunizmu z perspektywy postkolonialnej. Postawę Polaków w tym wypadku określa w zasadniczym wymiarze dyskurs

10 Na taką motywację wyboru przez reżysera dramatu Profesjonalista wskazują też recenzenci i publicyści komentujący na łamach polskiej prasy przedstawienie Bugajskiego, por. m.in.: J. Cieślak, Ludzie wypaleni. Niedoskonate, ale ważne przedstawienie Ryszarda Bugajskiego, „Rzeczpospolita”, 1.03.2005; D.J. Ćirlić, Pamięć agenta, ,Rzeczpospolita”, 25.01.2005.

11 Szczegóły opinii na temat spektaklu Bugajskiego jako głosu w toczącej się wówczas w przestrzeni publicznej debacie o lustracji przytacza D. Szałęga, op. cit. 
emancypacyjny, w którym PRL usytuowany zostaje w pozycji państwa zależnego od ZSRR jako hegemona realizującego politykę imperialną (przy czym Związek Radziecki postrzegany jest z perspektywy tradycji łacińskiej, stanowiącej horyzont polskiej kultury narodowej, jako barbarzyński najeźdźca). Natomiast w postjugosłowiańskiej Serbii te wątki zależnościowe - co zrozumiałe z uwagi choćby na status Socjalistycznej Republiki Serbii w ramach federacji jugosłowiańskiej oraz względnie niezależną pozycję Jugosławii na arenie międzynarodowej - zdają się nieobecne w lokalnym porządku pamięci albo po prostu nieistotne (inaczej rzecz się będzie miała w przypadku Chorwacji). W związku z powyższym, jeśli uzgodnienie doświadczeń polskich i serbskich jest tu możliwe, to właśnie dlatego, że zasadniczym przedmiotem krytycznej oceny działania systemu, i to pokazuje dramat Kovačevicia, winno być „,zniewolenie sumień i umysłów” - cecha dystynktywna totalitaryzmu.

Nawet pobieżny przegląd realizacji serbskich dramatów prezentowanych na scenach polskich teatrów dowodzi, iż o wyborach repertuarowych decyduje w pierwszym rzędzie zaangażowanie danego twórcy w aktualne problemy polityczne i społeczne. Przykładem może być żywa reakcja polskiej sceny na rozpad Jugosławii i będące jego następstwem zbrojne konflikty na Bałkanach. Odpowiedzią na nie była szeroko komentowana w prasie inscenizacja dramatu macedońskiego autora Dejana Dukovskiego Beczka prochu (Bure baruta) w reżyserii Grażyny Kani, zrealizowana przez gdański Teatr Wybrzeże ${ }^{12}$, a także liczne adaptacje sceniczne Sytuacji rodzinnych (Porodične priče) Biljany Srbljanović13. Te oraz inne, podobne inicjatywy dawały polskiemu odbiorcy, mniej lub bardziej udanie, asumpt do krytycznej konfrontacji z obrazem Bałkanów w wariancie kształtowanym przez zachodnie mass media. Nietrudno dostrzec, iż przyjęcie protekcjonalnej perspektywy zachodniego demokratycznego świata sprzyjało transmisji stabloidyzowanego obrazu tego regionu. Nieuchronnie był on naznaczony piętnem bałkanizmu - pod tym pojęciem rozumiem za Mariją Todorową mechaniczną projekcję pewnego kompleksu stereotypowych wyobrażeń o Bałkanach, tworzącego kognitywne ograniczenie jego percepcji ${ }^{14}$. Tak zideologizowana wizja bałkańskości oddziaływała także na inicjatywy teatralne, stając się najchętniej eksploatowanym nośnikiem pomysłów inscenizacyjnych, a zarazem podstawą komunikacji z odbiorcą. Próba równoważenia tej optyki refleksją na temat „,bałkańskiej europejskości” krajów postjugosłowiańskich, w tym Serbii, była również obciążona uprzywilejowaniem zachodniego modelu cywilizacyjnego.

12 Polska premiera spektaklu według dramatu Dejana Dukovskiego odbyła się w Teatrze Wybrzeże w Gdańsku 7.04.2007 r.

13 Polskie prapremiery spektakli Biljany Srbljanović: Sytuacje rodzinne, reż. Krystyna Meissner, Wrocławski Teatr Współczesny im. Edmunda Wiercińskiego (21.01.2000 r.); Upadek, reż. André Hübner-Ochodlo, Teatr Atelier im. Agnieszki Osieckiej w Sopocie (2.08.2002 r.); Ameryka - część druga, reż. Agnieszka Lipiec-Wróblewska, Teatr Telewizji (19.03.2006 r.), Szarańcza, reż. Paweł Szkotak, Teatr Polski w Poznaniu (25.10.2008 r.); Barbelo, o psach i dzieciach, Teatr im. Stefana Jaracza w Łodzi (15.01.2011 r.).

14 M. Todorova, Dizanje prošlosti u vazduh. Ogledi o Balkanu i Istočnoj Evropi, przeł. z j. ang. S. Glišić, Beograd 2010, s. 163-164. 
Nie trzeba przypominać, że lata 90. XX wieku oraz początek następnej dekady to okres wzmożonego zainteresowania sytuacją w Serbii, przede wszystkim z uwagi na konflikt w Kosowie, triumf wspierającego postawy nacjonalistyczne reżimu Slobodana Miloševicia, a wreszcie bombardowania NATO w 1999 roku oraz izolację polityczno-gospodarczą kraju. Medialna informacja o tej sytuacji kształtowana była w Polsce zasadniczo zgodnie z perspektywą dominującą w oficjalnych przekazach państw zachodnich. Kluczowe znaczenie miało tu podkreślanie cywilizacyjnego dystansu, dzielącego rzekomo oba światy, co sprzyjało zarówno demonizacji, jak i egzotyzacji obrazu Serbii, którą uznano za encyklopedyczny przykład bałkanizacji, rozumianej potocznie jako podszyty konfliktami rozpad oraz degradacja cywilizacyjna i etyczna społeczeństwa, prowadząca do zanegowania wartości emblematycznych dla kultury europejskiej ${ }^{15}$. Ów wizerunek zinternalizowany przez Serbów w ramach gestu samokolonizacyjnego stał się zresztą podstawą eksportowego autostereotypu, chętnie konsumowanego i reprodukowanego przez zglobalizowaną popkulturę. Ożywiał i utrwalał on typowe wyobrażenia o regionie, tworzące łatwy klucz interpretacji aktualnych bałkańskich kryzysów ${ }^{16}$.

O ile zatem namysł nad doświadczeniem komunizmu, czego przykładem są inscenizacje dramatów Kovačevicia, mógł stanowić punkt wyjścia dla rozpoznania łączących oba społeczeństwa podobieństw, o tyle konsekwencje jego upadku - pokojowa transformacja w Polsce oraz eskalacja konfliktów narodowościowych na Bałkanach i zaangażowanie w nie Serbii - skłaniały do zdecydowanego zaznaczania różnicy. Podstawę zrodzonego na tym gruncie negatywnego stereotypu stanowiło przekonanie o tym, iż Serbowie, nastawieni antymodernizacyjnie i skrajnie nacjonalistycznie, stanowią zagrożenie dla „naszego”, tj. europejskiego, stabilnego porządku, ucieleśniającego system humanistycznych wartości. W myśl tej wizji doprowadzili oni do niekontrolowanej eksplozji utajonego barbaryzmu, co stało się możliwe za sprawą trwałości trybalnych czy też po prostu prymitywnych struktur mentalnych, wpisanego w kulturę serbską imperatywu apologii etniczności, a także dzięki żywotności postaw esencjalizujących doświadczenie autochtoniczności oraz konfrontacyjnemu stosunkowi do wszelkiej odmienności.

Przewartościowanie takiego wizerunku wydawało się możliwe tylko poprzez ukazanie tych obszarów serbskiego doświadczenia kulturowego, które osadzone są w innych niż powyżej wymienione strukturach aksjologicznych. W sferze najnowszej dramaturgii serbskiej takiej alternatywy dostarcza pisarstwo Biljany Srbljanović. Atutem tej twórczości jest polemiczny stosunek do serbskiego patriotyzmu, budowanego w aurze narodowej megalomanii na fundamencie, o czym

15 O ewolucji pojęcia bałkanizacji pisze obszernie Marija Todorova w pracy Bałkany wyobrażone (przeł. P. Szymor i M. Budzińska, Wołowiec 2008, s. 79-89). Wydaje się, że wydarzenia związane z rozpadem Jugosławii doprowadziły do kolejnej resemantyzacji tego - i tak obciążonego pejoratywnymi konotacjami - terminu, który zaczął być odnoszony nie tylko do zjawisk natury politycznej (czyli „,narodowego rozdrobnienia istniejących wcześniej, dużych jednostek geograficznych i politycznych”; M. Todorova, Bałkany ..., s. 79), ale także do procesów psychospołecznych, towarzyszących określonym przemianom geopolitycznym.

16 V. Goldsvorti, Izmišljanje Ruritanije - imperijalizam mašte, przeł. z j. ang.V. Ignjatović, S. Simonović, Beograd 2005, s. 248. 
przekonuje autorka, abstrakcyjnego w swej istocie imperatywu umiłowania ojczystej ziemi oraz wyobrażonej identyfikacji z narodem definiowanym według kryteriów etnicznych. Srbljanović podchodzi do tego problemu z pozycji osoby, dla której osobiste doświadczenie emigracji stanowi istotne narzędzie relatywizacji obrazu własnej kultury i własnego narodu, ale także umożliwia krytyczny stosunek do zmityzowanego wizerunku zachodniego świata.

Wydaje się, że właśnie owo naznaczone dystansem spojrzenie, zawieszające jednoznacznie wartościującą dychotomię i jednocześnie niewykluczające zaangażowania w sprawy polityczne i społeczne, zapewnia przychylny odbiór tej twórczości poza granicami Serbii. Przez polskich twórców teatralnych Biljana Srbljanović jest postrzegana jako autorka, która - niezależnie od tego, czy akcja jej dramatów rozgrywa się w Serbii, czy też w innych miejscach na świecie - mierzy się z problemami kluczowymi dla ponowoczesności. Tym samym kontekst odczytań jej utworów zyskuje wymiar uniwersalny albo - i to chyba trafniejsze w odniesieniu do serbskiej dramatopisarki określenie - globalny. Jak podkreślają polscy twórcy i krytycy teatralni, chętnie odczytujący jej twórczość w kluczu nowego brutalizmu ${ }^{17}$, ukazuje ona pęknięcia współczesnej rzeczywistości w pierwszym rzędzie na poziomie zjawisk codziennych: sytuacji rodzinnych i szkolnych, zwykłych relacji międzyludzkich - miłosnych, koleżeńskich, przypadkowych. To zaś ułatwia polskiej (a pewnie i każdej innej) publiczności identyfikację z bohaterami i poruszaną problematyką, co z kolei zapewnia przesłaniu teatralnej adaptacji czytelność i zrozumiałość ${ }^{18}$. Ten typ uczestnictwa w przestrzeni społecznej Goran Injac określa mianem postpolityczności, którą za Aną Vujanović uznaje za tendencję charakterystyczną dla dramaturgii serbskiej po upadku reżimu Miloševicia $^{19}$.

Dla polskiego odbiorcy - doświadczającego głębokich zmian społecznych, a zwłaszcza gruntownych przeobrażeń stylu życia - istotne wydaje się zwłaszcza wydobyte przez autorkę napięcie pomiędzy światem tradycyjnych wartości, jak się okazuje wyjałowionych, nieprzystających do aktualnych warunków, a nowoczesnością, do której bezwarunkowo aspirujemy, mimo iż w ostatecznym rozrachunku nie ma ona dla nas satysfakcjonującej oferty. Symbolicznym znakiem rozziewu pomiędzy tymi dwiema rzeczywistościami czyni autorka w swych utworach konkretne historyczne wydarzenia, mające znamiona wydarzeń granicznych - wojna w Jugosławii, upadek muru berlińskiego (Supermarket), atak na wieże WTC w Nowym Jorku (Amerika - drugi deo / Ameryka - część druga). Każde z nich przenika i w niemal mistyczny sposób determinuje losy bohaterów. Przegrana jednostki jest dla Srbljanović za każdym razem porażką cywilizowanego

17 J. Dziuba, Antropologia relatywna. Z problematyki recepcji postmodernistycznej dramaturgii serbskiej i chorwackiej w Polsce [w:] H. Mieczkowska, E. Solak, P. Fałowski, N. Palich, Tradycja $i$ wyzwania. Metodologia badań slawistycznych XX i XXI wieku, Kraków 2015, s. 349-357.

18 Por. m.in.: D.J. Ćirlić, Królowa Ubu, „Dialog”2001, nr 3, s. 180; R. Pawłowski, B. Srbljanović (wywiad), Świat moga zmieniać nowi ludzie, „Gazeta Wyborcza”, 4.05.2007 (nr 103); M. Lenarciński, Zbrodnie we współczesnej Serbii i średniowiecznej Szkocji, „Dziennik Łódzki”, 2.04.2008 (nr 78).

19 G. Injac, „Nie rozpoznaję tego gatunku” - dramat jako struktura polityczna [w:] Postpolityczność..., s. 15 . 
świata. Nie tylko bowiem ujawnia ona immanentny absurd życia, irracjonalność oraz bezsensowny i pozbawiony transcendentnej racji tragizm ludzkiej egzystencji, ale także wyraża zwątpienie w porządek oparty na kartezjańskim optymizmie i w rozumny podmiot będący tego ładu gwarantem ${ }^{20}$.

\section{Dramat obrzędowy jako obszar poszukiwań teatralnych}

Odrębnym, a dla polskiego teatru niezwykle istotnym źródłem inspiracji artystycznych jest serbska (a także szerzej - bałkańska) tradycyjna kultura ludowa, bogata w źródłowe formy widowiskowe (performatywne, prototeatralne). To zainteresowanie dotyczy w pierwszym rzędzie teatrów niezależnych, poszukujących, takich jak Teatr Wiejski Węgajty czy Ośrodek Praktyk Teatralnych Gardzienice, które łączą pracę par excellence teatralną z elementem badań etnologicznych. Ów badawczy, naukowy impuls motywuje oba zespoły do wypraw etno-artystycznych, antropologicznych badań terenowych, prowadzonych wśród enklaw kultur tradycyjnych na całym świecie - są to najczęściej obszary kulturowego pogranicza, jak choćby rejon północno-wschodniej Serbii, zamieszkany przez Serbów i Wołochów (Wlachów). Chodzi tu bowiem o miejsca, w których po dziś dzień kultywowane są dawne, archaiczne widowiska kulturowe. Są one postrzegane przez twórców Węgajt czy Gardzienic (zgodnie z intencją mistrzów: Eugenia Barby czy Jerzego Grotowskiego) nie tyle w duchu folkloryzmu - jako matryca inscenizacyjna, ile jako narzędzie doskonalenia warsztatu aktorskiego oraz rezerwuar środków artystycznego wyrazu ${ }^{21}$.

W działaniu tak Gardzienic, jak Węgajt podstawowym tworzywem przedstawień oraz przestrzenią pracy aktorskiej zbiorowej i indywidualnej jest muzyka, owa - jak dowodzili Mieczysław Limanowski i Juliusz Osterwa - via naturalis spektaklu. Z tego względu niewyczerpywalnym źródłem dźwięków o proweniencji archaicznej, melodii, pieśni, technik wokalnych jest bogata fonosfera Bałkanów, w tym również Serbii, oraz różnorodne instrumentarium charakterystyczne dla regionu. W doświadczeniu Gardzienic znaczenie owej fonosfery wiąże się z formułowaną przez takich badaczy, jak Stanisław Vincenz, Tadeusz Zieliński czy Stefan Srebrny, koncepcją, według której w folklorze Bałkanów - traktowanych jako obszar pogranicza, a więc $\mathrm{z}$ jednej strony terytorium oddalonego od centrum, z drugiej dynamicznej przestrzeni współistnienia, interferencji, spotkania $^{22}$ - ujawnia się koincydencja światów: greckiego (starożytnego) i słowiańskie-

20 Przedsięwzięciem inscenizacyjnym, które można uznać za przykład odejścia od interpretacji doraźnie kontekstowych, publicystycznie traktujących aktualność serbskich utworów, jest poetycki, wizjonerski spektakl Słownik chazarski. Łowcy snów, wyreżyserowany przez Pawła Passiniego na motywach powieści Milorada Pavicia w Teatrze im. Jana Kochanowskiego w Opolu w 2012 r.

${ }^{21} \mathrm{O}$ inspiracjach tradycyjnymi formami ludowymi regionu Bałkanów w polskim teatrze i myśli teatralnej piszę obszerniej w artykule „Może tam kiedy boga Dionizosa wzywano...”. Wyprawy artystyczno-badawcze na Bałkany polskich teatrów poszukujących, „Pamiętnik Słowiański” 2011, z. 7 , s. $123-140$.

${ }^{22}$ Por. rozważania na temat kategorii pogranicza jako kategorii kulturowej zawarte w książce M. Dąbrowskiej-Partyki, Literatura pogranicza, pogranicza literatury, Kraków 2004, s. 23. 
go, zaświadczająca o duchowej jedności Europy. Ta myśl stała się na przełomie lat 90. i pierwszej dekady XXI wieku mottem wypraw terenowych ,śladami antyku" na Bałkany, w tym w 2003 roku także do Serbii. To zainteresowanie związane było z pracą nad spektaklami opartymi na tekstach starożytnych autorów ( $\mathrm{Me}$ tamorfozy według Apulejusza, Elektra i Ifigenia $w$ A... na motywach dramatów Eurypidesa) oraz z opracowaniem nowoczesnych rekonstrukcji pieśni greckich przez działającą przy Teatrze Gardzienice Orkiestrę Antyczną ${ }^{23}$.

Inną, obok muzyki, formą tradycyjną, wyraziście reprezentowaną na Bałkanach, którą polscy artyści poszukujący traktują jak tworzywo pracy teatralnej, jest ustna narracja, żywa opowieść, gawęda. Stanowi ona, obok pieśni etnicznej, strukturalną osnowę działań scenicznych w spektaklach Teatru Węgajty - jest tu czynnikiem porządkującym akcję, określa formę i miejsce gestu aktora. Przede wszystkim jednak jest lekcją specyficznego podejścia do słowa scenicznego, które twórcy wywodzą z tradycyjnej sztuki opowiadania jako formy w swym pierwotnym synkretyzmie performatywnej. Jej przykłady przedstawiciele zespołu gromadzili w latach 90. m.in. właśnie podczas wypraw do Serbii i Macedonii.

W przypadkach obu teatrów w procesie transpozycji teatralnej, opartej na antykizacji południowosłowiańskiego folkloru oraz na przetworzeniu tkwiącego w nim pierwiastka archaicznego (autentycznego, ,nie do podrobienia”) w jakość nośną energetycznie i znaczeniowo, także dziś pobrzmiewa impuls romantyczny, a zwłaszcza Mickiewiczowska wizja poetyckich transpozycji ludowości wyłożona w Lekcji XVI paryskiego cyklu wykładów wieszcza, zatytułowanej $O$ dramacie słowiańskim. Pod tym względem wpisują się one w przyjęty przez oba zespoły model własnej artystycznej tożsamości, która konstytuuje się w głębokim dialogu z przeszłością.

Należy przy tym podkreślić, iż omówionych tu niezależnych przedsięwzięć artystycznych nie można postrzegać jednowymiarowo - jako teatralnej archeologii czy też podszytej sentymentem i nostalgią próby rewitalizacji dawnych form. Realizowane w czasach pogłębiającego się kryzysu na Bałkanach i towarzyszącego mu politycznego wykluczenia Serbii przedsięwzięcia Węgajt i Gardzienic polegały na praktykowaniu idei, a także stawały się poszukiwaniem alternatywy, niezależnej od dominujących dyskursów drogi poznania, próbą mediatyzacji, a więc budowania płaszczyzny wzajemnej komunikacji, w której doświadczenie artystyczne zyskiwałoby szczególną intersubiektywną ważność. Niejako wbrew ogólnemu, zwłaszcza ugruntowywanemu w mass mediach, ostracyzmowi zamysł ten realizowano poprzez afirmację tych fenomenów kultury serbskiej, w których - pod prąd potocznego oraz oficjalnego dyskursu, a w duchu nowej ekologii kulturowej - dostrzegano nośniki uniwersalnych wartości, prawdziwie humanistyczny potencjał. Jednocześnie folklor, kultura ludowa - spartykularyzowane i wykorzystywane przez esencjalizujące etniczność ruchy nacjonalistyczne - w praktyce polskich teatrów były ukazywane jako wspólne dziedzictwo, zapomniane formy kultury europejskiej, żywe laboratorium pamięci. W tym sensie propozycja Gar-

23 Z Orkiestry Antycznej wyłonił się w 2004 roku Teatr Chorea, który również w swej pracy wykorzystuje elementy tradycji bałkańskich, zwłaszcza muzycznych, widząc w tej inspiracji narzędzie odnowy form teatralnej komunikacji aktora i widza. 
dzienic i Węgajt, by spojrzeć na Serbię oraz inne kraje bałkańskiego Południa w kluczu odnowionego mitu romantycznego i by w dobrze pojętej mityzacji dostrzec alternatywę dla stereotypizacji, wyznaczającej horyzont potocznej wiedzy o tym obszarze, ma charakter kontrkulturowy i w sposób znaczący niuansuje polski kulturowy obraz Serbii.

Przedsięwzięcia dramatyczno-teatralne konfrontujące polskiego twórcę oraz odbiorcę z odmienną kulturowo twórczością serbskich autorów, adaptacyjne, ale także podejmujące z nią dyskusję, mocno wpisują się we współczesne tendencje percepcji inności. Z jednej strony aktualizują nośne dyskursy: orientalistyczny i bałkanistyczny, z drugiej zaś coraz częściej uświadamiają sobie ograniczenia wynikające $z$ reprodukcji zastanych matryc poznawczych. Próbują je więc przekraczać, poszukując w inności probierza własnych doświadczeń historycznych, społecznych i kulturowych. Nader często dążą także do ustanowienia własnej, niejako autonomicznej (bo opartej na zaangażowaniu, kreacji i poszukiwaniu indywidualnej odpowiedzi) logiki spotkania z serbskim „Innym”24.

\section{Bibliografia}

Antologia współczesnego dramatu jugosłowiańskiego / Antologija savremene jugoslovenske drame, oprac. O. Lakićević, Łódź 1988.

Bogusławska M., ,, Może tam kiedy boga Dionizosa wzywano... ”. Wyprawy artystyczno-badawcze na Bałkany polskich teatrów poszukujących, „Pamiętnik Słowiański” 2011, z. 7.

Cieślak J., Ludzie wypaleni. Niedoskonałe, ale ważne przedstawienie Ryszarda Bugajskiego, „Rzeczpospolita”, 1.03.2005.

Ćirlić D.J., Królowa Ubu, „Dialog” 2001, nr 3.

Ćirlić D.J., Pamięć agenta, ,Rzeczpospolita”, 25.01.2005.

Dąbrowska-Partyka M., Literatura pogranicza, pogranicza literatury, Kraków 2004.

Dąbrowska-Partyka M., Poleżé na liściach laurowych, albo czego nie wolno tlumaczowi [w:] Świadectwa i mistyfikacje. Przed i po Jugosławii, Kraków 2003.

Dziuba J., Antropologia relatywna. Z problematyki recepcji postmodernistycznej dramaturgii serbskiej $i$ chorwackiej $w$ Polsce [w:] H. Mieczkowska, E. Solak, P. Fałowski, N. Palich, Tradycja $i$ wyzwania. Metodologia badań slawistycznych XX i XXI wieku, Kraków 2015.

Goldsvorti V., Izmišljanje Ruritanije - imperijalizam mašte, przeł. z j. ang.V. Ignjatović, S. Simonović, Beograd 2005.

Kalita H., Bibliografia jugoslovenske drame na pozornicama u Poljskoj 1910-1985, „Scena” 1986, br. 6.

Lenarciński M., Zbrodnie we współczesnej Serbii i średniowiecznej Szkocji, „Dziennik Łódzki”, 2.04.2008 (nr 78).

24 Pouczającej lektury dostarczają w tym względzie antologie: Postpolityczność. Antologia nowego dramatu serbskiego, a także Serbska ruletka. Dramat serbski po 1995 roku (red. A. Cielesta, L. Małczak, D. Zwierzchowska, Katowice 2011). Otwierają one, w moim przekonaniu, nowy rozdział w recepcji serbskiego dramatu i teatru. 
Pawłowski R., Srbljanović B. (wywiad), Świat moga zmieniać nowi ludzie, „Gazeta Wyborcza", 4.05.2007 (nr 103).

Postpolityczność. Antologia nowego dramatu serbskiego, wybór i red. G. Injac, Kraków 2011.

Serbska ruletka. Dramat serbski po 1995 roku, red. A. Cielesta, L. Małczak, D. Zwierzchowska, Katowice 2011.

Szałęga D., Obecny Nieobecny. Polska recepcja dramatów Dušana Kovačevicia, „Slavica Wratislaviensia” CLIV, 2011.

Todorova M., Bałkany wyobrażone, przeł. P. Szymor, M. Budzińska, Wołowiec 2008.

Todorova M., Dizanje prošlosti u vazduh. Ogledi o Balkanu i Istočnoj Evropi, przeł. z j. ang. S. Glišić, Beograd 2010. 